Kohl: a Journal for Body and Gender Research

Vol. 6, No. 1 (Summer 2020)

\title{
Reviving Pan-Arabism in Feminist Activism in the Middle East
}

\author{
Maria Najjar
}

\begin{abstract}
:
This essay is a preliminary attempt to explore the potential of a feminist, Pan-Arab ideology in relieving some of the tensions in feminist movement building in the Middle East and North Africa region. In its current formulation, regional feminisms suffer from compounded inefficiencies due to fragmentations in grassroots, civil society organizing; an overreliance on the state and state actors including NGOs and discourses of neoliberal development; and a narrow focus on a human rights approach for feminist action. Nonetheless, the present also offers a number of opportunities that are often omitted in our analysis of these disabling tensions. These include women's growing salience and their increasing presence in public, political spaces of mobilizing, organizing and resistance, which has facilitated communication and negotiation with and within state apparatuses. Opportunities also exist thanks to the enabling and connective nature of the Internet for the purpose of transnational feminist organizing. Crucially, it is the idea that a single, organized and unified movement will gather more support, and collect greater influence than would be the case if these movements remained in their divided and atomized states. Ultimately, this piece is an exercise of feminist imagination one that envisions the ways in which a regional feminism can emerge based on an active struggle against patriarchy in all its manifestations.
\end{abstract}




\section{Introduction}

The present is an interesting and exciting time to examine tensions in feminist movement building in the Middle East and North Africa region (MENA). On the one hand, we find ourselves in the slowly evanescent momentum of the "Arab Spring," a period of public upheaval against what were perceived to be tyrannical and authoritarian regimes of oppression across the region. The uprisings spanned multiple countries, albeit at different timings, and with distinct manifestations and impacts, including Tunisia, Egypt, Libya, Yemen, Bahrain, Morocco, Iraq, Algeria, Lebanon, Jordan, and Sudan. However, these public revolts now share a crucial commonality. Khamis $(2018$, p. 8) explains how they have become an "important turning point in contemporary Arab history, and [as] a central, focal point which had numerous implications for Arab women's ongoing political, social, and legal struggles." Indeed, women were active actors in these protests as they engaged in a multifaceted battle against oppressive regimes that threatened their livelihood as citizens on the one hand, and as gendered and racialized citizens on the other. It would be fallacious to draw a causeand-effect relationship between the uprisings and long-term socio-political change; however, it is safe to say that women's presence in public spaces of resistance and activism, occupying various norm-defying roles, has translated into newfound agency and power that remain tangibly visible even nine years later. Looking at the fundamental role that women have played, and continue to play, in the more recent protests in Sudan, Algeria, and Lebanon, it becomes evident that the lines between the traditionally feminine private and the masculine public spheres have been blurred.

The present is also a time of turbulent geo-political strife across the MENA region, which poses its own challenges with regards to regional feminist movement building. From the ongoing protests against the corrupt political elite in Lebanon to the recent "peace" plan enacted by the Trump administration, these dynamics present new obstacles and opportunities for any type of activism in the region. Crucially, we are amidst a global pandemic that requires, more than ever, regional and transnational solidarity and cooperation, and a reassessment of the inadequacies of the globalized neoliberal world we inhabit - a world that disproportionately impacts the most vulnerable groups in society, including women and children. It is within this context of overlapping multifaceted tensions that it becomes important to re-evaluate the state of feminism and its movements across the MENA region. This exercise allows us to locate the continuing tensions and the recurring challenges to activism in the region, but also to envision novel and contextuallyrelevant ways to expand the movements' power and influence. This recapitulation invites us to assess the ways in which institutions and organizations, global, regional, and local, can act as vehicles for socio-political change or, on the contrary, as active sites of struggle.

As such, this piece is an attempt at this endeavor. I begin by exploring the historic attempts, by Arab feminists, at building a regional feminist alliance, followed by a specific assessment of the present tensions and opportunities in feminist movement building in the region. Both of these exercises then allow me to imagine and propose a Pan-Arab feminist movement as a potentially rewarding and efficient avenue for movement building in the MENA region. I would like to emphasize the previous use of the verb imagine, as this piece falls directly within the realm of feminist imaginaries, and is specifically geared towards an exploratory 
conception of organizing and mobilizing in the context at hand. Importantly, this is also an invitation for others to consider the potential of such an imaginary and to build on these initial ideas.

\section{Definitions and Distinctions}

Before I begin, I must address the limitations and tensions of the chosen terminology. By championing a PanArab feminist movement, I am assuming a solidarity based on two axes: the first one being an imagined "Arab" collectivity and the second being an imagined collectivity of "women," thereby creating an alliance on the basis of common gender and national denominations.

I am cognizant that both terms have exclusionary tendencies in that they fail to encompass the diverse material realities that are characteristic of the region at hand. Specifically, assuming a homogeneity based on an Arab identity alienates those communities that have been historically disadvantaged, displaced, and oppressed by the Arab peoples. These communities include, but are not limited to the Armenians, the Berbers, the Nubians, but also the significant groups of migrant domestic workers across the region. Forcing these communities into the umbrella term of "Arab" would be an act of epistemic violence. Moreover, assuming homogeneity on the basis of gender ignores the myriad ways that gender connects to other aspects of social identity such as race, ethnicity, or nationality (Alcoff, 2017, p. 46).

It also does little for effective solidarity and alliance building. Mohanty explains that "feminist work must be deeply collective and that this deep collectivity calls for struggle through, with and over... borders in our everyday lives" (as cited in Pohlhaus Jr, 2017, p. 51). Indeed, she calls for a "feminism for the 99\%" that engages with and across differences among women - a feminism that connects to the "material praxis of the diverse, gendered and racialized communities of women (cis and trans) across the spectrum of class, sexuality, ability and citizenship status" (Mohanty, 2017, p. 19). As such, she champions a solidarity on the basis of a collective struggle and resistance to common structures of oppression and domination. Grounded in this idea, a Pan-Arab feminist movement has less to do with an imagined collectivity based on a shared identity as Arab women, and more to do with an alliance constructed on the basis of an active struggle against the various manifestations of patriarchy across the MENA region. I echo Linda Alcoff's contention that:

Solidarity can only be achieved, then, through piecemeal or partial coalitions, best pursued on the basis of concrete issues, rather than on the articulation of a thin or artificial collectivity organized around ideas about freedom from gender. And piecemeal coalitions will require a kind of multicultural negotiation in which contested narratives will have to be brought into some measure of alignment. (2017, p. 47)

A Pan-Arab feminist coalition is one that acknowledges the diversity and mediations of gendered experiences, but shares a common ideological opponent and that is, patriarchy in all its manifestations. Commonality here is achieved and solidified through a transformatory agenda against patriarchy as a system of exploitation and domination. 
It is important to add that, in light of current events in the United States and the world, with the protests against the continued oppression of Black communities by white supremacist agendas, transnational solidarity is crucial, now more than ever. This is because, while vastly distinct in impact and duration, Arab communities are also targets of disproportionate, racially-justified policing, criminalization and discrimination, especially since the beginning of the US' War on Terror in 2001. Black and Arab solidarity is thus based on a shared struggle against a global project of white supremacy and imperialism that treats both groups as "foreign entities" that need to be controlled and contained. This project is not specific to the US, and also encompasses the prevailing neocolonial interventions of European powers in the MENA region. With this in mind, political alliances and solidarity become political choices that we intentionally make in the name of this shared struggle (American-Arab Anti-Discrimination Committee [ADC], 2020). The common identifier thus becomes this struggle, not the identity "Arab."

Pan-Arabism is distinct from other nationalist political ideologies. A Pan-Arab ideology is often subsumed under the umbrella of Arab Nationalism or Arabism, which contributes to its commonly attributed definition as a nationalist political ideology that champions the political, cultural, and economic unity of Arab states (Danielson, 2007, p. 17). Moreover, this definition rose in prominence at a historical juncture when Arab nations were attempting to resist domination by, and dependence on, first, the Ottoman Empire and more recently, Western powers (FM, 2016). It is also this conceptualization that accords Pan-Arabism its historically negative connotation as fascist and anti-democratic. However, for the purpose of this piece, I attempt to distance Pan-Arabism from this definition as it fails to grasp the intended meaning for feminist purposes, and to consider the present socio-political context within which Pan-Arab feminism can emerge. Instead, I base my definition of Pan-Arabism on Temlali's claims on the emergence of a new form of Arab unity, a unity of sentiment that is:

Based less on ethnic or racial considerations than on a broadly political stance: rejection of foreign domination, aspiration to freedom, belief in the possibility of change. This new sentiment - forged in the crucible of bloody battles against despotism and in pursuit of social justice - has little in common with the attitudes that flourished during the hey-day of Arab nationalism which, while anti-imperialist in nature, were also inimical to human and democratic rights. $(2016$, p. 49)

In a post Arab Spring context, Pan-Arabism is thereby best understood as a shared desire for freedom and social justice that spans the nations of the MENA region, and binds them with a common goal to mobilize and organize towards that end. Within this, Pan-Arab feminism is defined as the grouping of the multiple, feminist, local and national, and individual and organizational agents that have come together in active struggle to collectively and collaboratively push for the dismantling of patriarchy in all its social, political, economic, or religious manifestations.

It is this affective binding factor, the shared longing for social justice, that justifies the use of this specific term over others such as transnational feminism, for instance. Indeed, the latter fails to apprehend the affective component inherent to Pan-Arabism as it is primarily axed in decentering knowledge production from the West through collaborative exchanges that aim to de-homogenize women's struggles for justice (Nagar and 
Swar, 2010). In fact, Pan-Arab feminism works towards that end, but also carries a fundamental affective component.

Summing up, I have attempted to justify my usage of the term "Pan-Arab" by tending to the various tensions that such naming involves, and explaining that this terminology is merely symbolic as opposed to literal. It does not dictate the requirements for feminist alliance-building nor does it indicate exclusivity to "Arabs." It is a choice I have made in order to argue for greater feminist solidarity across the MENA region - a choice made due to the lack of a better term. This is also an invitation for a collective act of thought for more encompassing terminology.

\section{A (Brief) History of Pan-Arab Feminism: The Legacy of the Arab Feminist Union}

It is useful to begin this endeavor with a historical overview of the deployment of Pan-Arab feminism as an ideology for transnational feminist movement building in the MENA region. This exercise is important because, on the one hand, it reveals the shortcomings and the potentialities of a Pan-Arab feminist movement at a particular historical and socio-political juncture, and, on the other hand, its applicability and feasibility in present contexts. Crucially, however, this exercise is an act of solidarity, through which we acknowledge and honor the struggles, attempts, and victories of past feminism, but also celebrate the collectivity and continuity that underpins successful transnational feminist action. After all, feminism is not an event; it's a process.

The implementation of a Pan-Arab feminist ideology has been previously attempted by the Egyptian Feminist Union (EFU) in the 1940s, in response to the growing universalist tendencies of international feminist bodies that assumed homogeneity of women's circumstances, oppressions, and demands across contexts (Badran, 1995, p. 109). Specifically, as opposition to British colonization of Egypt and Palestine escalated in the 1930s, it became evident, within international feminist circles of which the EFU was a member, that imperial interests took precedence over gender interests. In turn, this increased tensions between members of the International Alliance of Women (IAW) and the EFU, the colonizers and the colonized, which prompted the latter to propose a regional alliance of feminists (Badran, 1995, p. 109). In other words, the union was partly born out of an early need to decolonize feminist knowledge and praxis in order to better address, and to redress, the diverse, material realities of Arab women. The creation of a Pan-Arab feminist movement thus emerged as a response to both the limitations of international feminism, and to growing nationalist tendencies and independence rhetoric in the region (Badran, 1995, p. 224). The Arab Feminist Union (AFU) was established in 1944, after Huda Shaarawi, the EFU, and delegations from Palestine, Lebanon, Syria, Trans-Jordan, and Iraq devised its agenda at the Arab Feminist Congress in Cairo that year (Badran, 1995, p. 239). That agenda predominantly aimed at reinstating women's political, legal, and economic rights across Arabic-speaking countries.

The AFU's existence was short-lived, however, following Shaarawi's death, the subsequent leadership crisis in the EFU, and, primarily, the latter's co-optation by Nasser's regime that was characterized by state consolidation policies at multiple levels (Badran, 1995, p. 248). More specifically, his rule was unconducive 
to independent politics, and much less to those with feminist intentions. Women's associations were required to be registered with the state who could then monitor and control their activities; representatives needed to acquire entry and exit visas to attend conferences, thereby allowing the state to also regulate their mobility; and ultimately, they decided which organizations were allowed to operate within Egypt's political apparatus (Badran, 1995, p. 249).

Nonetheless, the legacy left by the AFU is noteworthy. Badran (1995, p. 250) explains that the union created a regional structure that successfully responded to the various manifestations and alterations of patriarchy. Specifically, representatives from the AFU were acquainted with bargaining with states to advance both feminist and national causes (Badran, 1995, p. 250). Crucially, the AFU helped expand and unify feminist movements in the Arab world: "there was an optimism that a unified Arab feminist movement would hasten feminist achievements in countries of the Arab East in the new era of national independence" (Badran, 1995, p. 250).

The initial intention of the union resembles the one I envision for a Pan-Arab feminism in the present day. The execution of the union's actions was halted by interventions from "controlling centralized state regimes" in which independent politics of any kind were not welcome (Badran, 1995, p. 250). Nonetheless, at inception, in 1944, the idea of a Pan-Arab feminist movement was hailed by masculine Arab governments, although they disagreed with the ways the Arab feminists envisioned the role of women as full-fledged citizens and equals (Badran, 1995, p. 240). More specifically, the state viewed women's role primarily in terms of their contributions for nationalist projects, as mothers of the nation, and as naturally gifted for specific endeavors such as arts, culture and philanthropy (Badran, 1995, p. 241). It is my contention that the fate of Pan-Arab feminism would not be the same in its modern application and execution because of women's, and the people's, newfound agency, momentum, and power in the post Arab Spring era. In fact, this era marks a different political and social juncture, one that is more conducive to negotiations with and within state apparatuses. As I will demonstrate, this context, characterized by women's increased presence and salience in public spaces and their increased connectivity to others and each other, provides a far superior ground within which a transnational feminist movement can emerge. Nevertheless, this same context presents a number of tensions that render the task of feminist movement building in the region an increasingly challenging one.

\section{Tensions and Opportunities in Feminist Movement Building in the MENA}

As we examine the multiple tensions presented by the present context, the act of transnational movement building becomes an imaginative one that invites us to devise ways that work with, through, and across these tensions.

Women's active involvement in the protests of the Arab Spring has engendered new understandings of their role in the process of political and social reform. Indeed, in times of socio-political upheaval, traditional understandings of gender norms tend to lose their social currency for the greater good of the struggle (cooke, 
2016, p. 32). Specifically, women's presence in street demonstrations and public spaces becomes a temporarily acceptable occurrence. Indeed, history shows that, as soon as revolutions end, women are expected to return to the private spaces in which they are deemed to belong. Kandiyoti (2013) explains that women's ongoing involvement and persistence in matters of public life often results in violent and coercive retaliation mechanisms by the political patriarchy, or what she terms "masculinist restoration." This explains, for instance, the common deployment of rape as a means of constraining and discouraging women's participation in public domains. The revolutions that spanned the MENA between 2011 and 2015 saw an exponential increase in sexual violence towards women: Libya's Gaddafi, Syria's Bashar Al-Assad, as well as Egypt's Hosni Mubarak are among those that had ordered, in varying degrees of severity, the sexual intimidation of politically-active women during these revolutions (cooke, 2016, p. 37). However, absent from Kandiyoti's analysis, is women's newfangled agency in their pursuit of gender justice in the post-Arab Spring MENA. In other words, although women's bodies have been the targets of masculinist restoration action, it is not impeding their determination for their demands to be heard, acknowledged, and answered; instead, it is pushing them to mobilize creatively, both transnationally and collaboratively (cooke, 2016, p. 43). We may even label these reactions to masculinist restoration tactics as feminist retaliation that is marked by, not only demands for the recognition of women's rights, but crucially, an expectation of justice. There are a number of acts, attempts, and initiatives that have showcased these tactics of feminist retaliation over the past decades of feminist action. For instance, the \#EnaZeda movement that began in Tunisia in October 2019 has encouraged thousands of Tunisian women to speak out against sexual harassment in public spaces (Ben Salah, 2020). Similarly, in response to the harassment threats aimed at undermining Lebanese women as political actors of the revolution, a volunteering team of guards as well as social media accounts explicitly exposing harassers were created in order to make public spaces safe for all protestors (Wilson, Zabaneh and Dore-Weeks, 2019, p. 12). Across the region, imagery of women leading protests have dominated the media landscape, and have contributed to a steady process of normalizing women's public and political presence. Alaa Salah is an example of a Sudanese woman whose address to protestors on the roof of a truck has become the symbol of the 2018 protest; Malak Alaywe is another example of a Lebanese female activist whose "heroic" act of kicking a minister's bodyguard in the groin has echoed across the country as the Lebanese public fights the corrupt political elite (Allouche, 2020). With this observation, I am not suggesting that these acts are most representative of women's participation in protests. Indeed, women have occupied various, critical roles when it comes to mobilizing and organizing for these large-scale protests. Unfortunately, these revolutionary acts go unnoticed within the mainstream media that primarily focus on attention-grabbing imagery for the purpose of attracting audiences. By recalling such imagery, I am arguing that they constitute an important tool through which women's political and public presence is magnified.

The people's, and especially women's, newfound power and salience, along with the simultaneity of the uprisings across MENA countries, have engendered new forms of mobilizing that have transcended national borders. cooke's use of the label "transnational revolution" to characterize the uprisings best embodies this latter observation. In her poignant words, "no longer isolated events, the separate revolutions have created contrapuntal resonances so that energy in one place can revive exhaustion in another" (2016, p. 43). In contrast, Khamis (2011, p. 694) invites us to envision the impact of the Arab Spring on women's concerns with "cautionary optimism." While it is true that women have rallied in even the most oppressive or 
conservative of nations, namely Bahrain and Yemen, it has not necessarily engendered socio-political changes in their favor. However, key here is the observation that women's persistence, despite these seemingly disabling factors, signals the bravery, willingness, and continuity of their activism, which allows Khamis to conclude that "there is no turning back for Arab feminists" (2011, p. 694). Abou-Habib (2019) also underlines this new feminist energy of co-creation:

Within such a project (of co-creation), individuals and structures in power would no longer be able to co-opt spaces, voices, and resources, or ensure that the status quo remains unscathed. Simultaneously, the revolution has brought about a level of political growth and courage that is allowing most of us to call out such attempts, when they happen, as they happen.

Some of the tensions in feminist movement-building have been superseded by women's demands for change, and their determination to acquire said change. Furthermore, with the prominence of social media platforms, transnational communication and collaboration becomes possible between these various agents of change. The power of these platforms is evident as we examine the salience of cyberactivism in the MENA over the last decades, and how the Internet and information technology have enabled superior levels of civic engagement and have strengthened civil society. These tools are instrumental in alleviating what Khamis and Mili perceive to be the most pressing obstacle for regional feminist movement building: the fragmentation, division and polarization that has resulted from the absence of a strong and structured civil society $(2018, p$. 246). According to her, it is this absence of a consolidated, vibrant grassroots civil society at the national and regional levels, and the presence of a power vacuum that have partly limited the effectiveness of sociopolitical reform in many of the nations in question $(2018$, p. 246). It is my contention that this fragmentation is not an issue in and of itself; rather, it is the missed opportunity of uniting that has halted the success of socio-political feminist action. Transnational solidarity building with the aid of new technologies that facilitate information sharing, awareness building and promotes civic engagement can help build this unity. The story behind the emergence of local-level, popular committees (PCs) in Egypt is a case in point. These committees were created by a number of activists from civil society groups after the Mubarak regime withdrew police forces across Cairo, and released its prisoners onto the streets to attack protestors (Newsom and Lengel, 2012, p. 35). Some of these organizations remained functional even after the police was re-introduced, but now serve the civic role of improving socio-political life at the community level (Bremer, 2011, p. 72). Importantly, these PCs constitute a first, genuine, and grassroots initiative emerging from a historically-weak Egyptian civil society, and the first sign of effective collective action at the local level in Egypt (Bremer, 2011). These committees used social media to organize and mobilize on a local, national, and crucially, a regional scale, whereby Tunisian activists were prompted to provide their expertise and knowledge from the experiences of their own revolution that had occurred weeks before (Newsom and Lengel, 2012, p. 35; Bremer, 2011).

These platforms make visible the violence of authoritarian regimes, and showcase the revolutionary actions taken by the people to counter this violence. Given the mass audience that these tools can reach, it is safe to conclude that these platforms serve as galleries of inspiration and examples for other nations dealing with authoritarianism. I am not positing that social media and technology have triggered these revolutions; rather, 
I am arguing that they have facilitated the key processes of organizing and mobilizing on a revolutionary scale.

Other tensions in feminist movement building in the MENA region include an overreliance on the state and state actors for gender reform. This is accompanied by the fact that these actors, more often than not, operate within a narrow human rights framework and within discourses of neoliberal development that perpetuate and maintain the very structures responsible for the sustenance of power hierarchies. The human rights framework is problematic, first and foremost, because it assumes that legal reform leads to women's empowerment more broadly. According to Zaatari (2014, p. 57), a human rights framework contributes to the perpetuation of patriarchal structures, and the strengthening of the positions of those currently in power; indeed, instead of dismantling it, a human rights approach is simply seeking to acquire a part in it. This is not to say that these gains are not praiseworthy or important, but they must be deployed as a tool, rather than an ultimate objective (Zaatari, 2014, p. 57). Importantly, this framework fails to address the intersectionality of women's oppression, and to account for the specificities of the context within which it operates. Being granted the right to work does little for women if the workplace remains a gendered, discriminatory institution, for instance. In other words, rights are indivisible. Broadly, in a region where the violations of human rights are left undocumented, unmonitored, and unsanctioned, the human rights approach appears futile on its own.

Furthermore, this approach, especially if it is modeled on Western notions of human rights, neglects the need for context-specific protection from gender-based, public, and private violence, and the recognition of sexspecific rights such as reproductive freedom. In 2012 and 2014, there were various attempts by feminist civil society groups in Lebanon to lobby for policies aimed at ending gender-based violence. Both ABAAD and KAFA had launched campaigns geared towards that goal, and, while they had opted for different mobilization tactics, they both involved the Lebanese state and religious leaders in their campaigns, thereby underlining the necessity of collaboration with the state for gender reform. This reliance on the state produces a paradox for these feminist associations: as they try to fill in the gaps left by the inability of the weak Lebanese state to fulfill its responsibilities, they also find their role as mobilizing and organizing agents for true collective action slowly diluting (Mitri, 2015). Furthermore, as the Lebanese state continues to lose its legitimacy and credibility, powerful, militant state groups (such as Hezbollah) step in to fill these gaps, thereby increasing their own legitimacy and power over Lebanese publics. Generally, the NGO-ization of civil society in Lebanon has had an impact on these organizations' ability to mobilize on a grand scale due to donor limitations, competition for funds, and the highly divided, sectarian nature of politics in the country. Nevertheless, the 2019 revolution in Lebanon holds promise and hope for a different political landscape, especially as sectarian divides begin to lose significance in some of the country's socio-political landscape.

In parallel, using Palestine as an example, Arda and Banerjee (2019, p. 23) illustrate how the process of NGO-ization has depoliticized the struggle in Palestine and is even responsible for normalizing occupation: "when efficient delivery of public services replaces political struggle, occupation becomes normalized. Social justice becomes another service to be delivered efficiently, which essentially means living under an efficiently organized occupation administered by the Palestinian Authority" (Arda and Banerjee, 2019, p. 27). The imposition of Western ideals of civil society and democratic governance misrepresents the struggle of the 
Palestinian people and perpetuates imperialist dynamics of power (Arda and Banerjee, 2019, p. 24). Moreover, the professionalization of NGOs turns social welfare missions into full-time salaried jobs; it increases competition between different organizations, strictly employs highly skilled and English-proficient staff, emphasizes performance instead of structural changes, and defines projects spatially and temporally (Islah, 2009, p. 38). This professionalization thereby leads to numerous exclusions and limitations, from language to the trickling down of donor aid to the more marginalized groups of women.

State feminism is defined as a tactic through which the state deploys feminist agendas strategically based on ulterior political motives. It is rather cosmetic or tokenistic, and is inextricably tied to broader national and geo-political interests. An example of such deployment is explained by Sukarieh's First Lady Phenomenon (2015, p. 575). Indeed, by taking Jordan's Queen Rania and Syria's Asma Al-Assad as examples, the author explains how these two women have become the face and ultimate representations of the modern Arab woman for international, regional and local audiences, starting in the 1990s, as Jordan and Syria were engaged in close politics with Western powers. These women's status and importance did not extend beyond these hidden political agendas. Moreover, they were given roles in care work and NGOs, as this was deemed to be the rightful domain of women, thereby delivering an illusion of progress and modernity whilst maintaining the clear division of genders.

To summarize, a number of tensions as well as opportunities define the operation of feminist movement building in the MENA region. These tensions take several forms, including an overreliance on already fragile state structures and actors such as NGOs, that operate within problematic neoliberal development frameworks that hinder tangible structural change. Division and fragmentation at the level of civil society presents a missed opportunity for feminist movement building to consolidate, organize, and mobilize for feminist action, facilitating the co-optation of feminist activism by states. Crucially, however, there also exists unique opportunities in our present for the creation of a powerful regional feminist alliance including feminist retaliation tactics and cyberactivism that trouble traditional understandings of the role of women in sociopolitical reform. It is within this climate that Pan-Arab feminism finds its place and purpose. It is important to mention that neither am I suggesting that such an ideology will fix the numerous structural obstacles and the political challenges that restrict feminist movement building in the region, nor am I intentionally omitting such issues from my analysis. I am cognizant of their existence and their disabling tendencies for purposes of feminist mobilizing and organizing. Rather, I am proposing Pan-Arab feminism as a value-adding mechanism to the various, already-existing local and national feminist movements. In other words, Pan-Arab feminism is useful, not because it will resolve the current tensions in feminist movement building in the Middle East, but because its creation would generate greater value, power, and influence than the individual and atomized state of regional women's movements today.

\section{Thinking Transnational}

The last section of this piece aims at exploring the why and how of thinking transnationally when it comes to feminist movement building in the MENA region. The benefits of the creation of a broader, regional feminist 
coalition emanate from an understanding that the whole is greater than the sum of its parts. In other words, binding together, in coalition, alliance, and solidarity, against the intersectional manifestations of patriarchy garners greater bargaining power, influence, and resources than would be the case if feminist action remains in its atomized and divided state. Indeed, with better coordination and consolidation, it is arguable that feminist agendas will progress more effectively and successfully. Specifically, the act of assembling the financial, social, political, and human capital in a single pool shared by a number of regional feminist organizations troubles the networks of dependency that exist between these organizations and states, professionalized NGOs, and donors. It also creates new, more reliable levels of dependency, solidarity, and unity between those agents working towards a common goal of social justice and sustained, radical, feminist change. This larger goal is collectively articulated, and is defined by the struggle against patriarchy in all its various mediations in the MENA region. From this broader objective, projects would be outlined simultaneously and collectively, and resources, from financial to political, are distributed accordingly. The idea behind common goal-setting is that it binds members together in active solidarity, under a single movement, and holds them accountable for its achievement. In this way, these collectively-defined projects that are actively designed to achieve the end goal would receive the appropriate means for action. The combined pool of resources is meant to be shared and replenished in the spirit of a shared community. The very act of pooling scarce resources is meant to trouble ideas of personal, tangible, and intangible property, binding members together to make the best use of such resources instead, in an attempt to achieve the common goal.

This new dependency releases these organizations from the burden of donor-driven, neoliberal agendas that are unrepresentative and unresponsive of local needs. It creates greater agency for organizations to decide for themselves the timelines, diversity, and scopes of their missions. Additionally, by joining forces, negotiation with states becomes more just, and reduces the risk of co-optation. This is amplified by the aforementioned agency, presence, and persistence of women on the ground that render co-optation a significantly less viable option for state actors.

A Pan-Arab feminist movement characterized by difference whilst united in a goal of dismantling patriarchal structures of oppression and exploitation allows feminists to tackle a range of issues collaboratively. Particularly, this conceptualization of feminism bypasses the narrow human rights framework currently adopted by women's movements. It would facilitate, instead, the adoption of a social justice framework that accounts for the intersectionality of identity and oppression, and that understands that rights are merely part of a much larger agenda for social change. This framework only works when multiple social locations are accounted for as this allows a more encompassing understanding of how social location, identities, and oppression intersect. McLaren (2017, p. 118) explains how this strategy

shifts the focus from gender oppression alone to a complex understanding of the ways that gender oppression is intertwined with other forms of oppression, and the need for collective action to challenge and change structural institutionalized oppression in all its various forms and institutional manifestations. 
A regional feminist alliance would facilitate this grouping of social locations. This alliance is thus rooted in transnational collaboration, dialogue and an active exercise of what Pohlhaus terms "epistemic gathering" (2017, p. 63). The latter is defined as "the work of making intelligible through our embodied epistemic practices that which dominant epistemic institutions continually and relentlessly render unintelligible in their own commitments to serve dominant interests." It is this kind of work that troubles present, binary, and imperialist understandings of the world. Crucially, this kind of work understands that identities are not static, and that they shift in response to, not only policy reform and the media, but also demands, desires, and meanings generated from below, by social movements themselves (Alcoff, 2017, p. 44). Consolidating feminists' efforts and therefore strengthening civil society facilitate the creation of new meanings, but also, avoid the creation of a power vacuum that allows for division and fragmentation to take place.

Finally, a transnational alliance allows an engagement in what Nira Yuval-Davis has termed transversal politics. This kind of politics facilitates the creation of solidarities between differentially socially located groups in three ways (1994, p. 193). First, it is based on standpoint epistemology, which posits that different positions engender different knowledge, and it is only through dialogue and exchange that these worldviews can be brought together to produce a more inclusive and encompassing worldview. Second, transversal politics involves an acknowledgment of different positionings and the power that comes with them, but treats difference with equal respect for all participants. Third, it distinguishes between identity, positioning, and value, whereby a single identity can generate multiple positions based on factors such as race, class, or ability. This, in turn, would generate a range of different socio-political values. Transversal politics is an important engagement for Pan-Arab feminism as it creates an alliance of advocates, as opposed to representatives of specific constituencies (which leads to identity-based politics) and causes. It groups these advocates in the pursuit of a common goal; there is no single "most authentic" voice, but a multiplicity of voices. In turn, this creates a situation where different participants work on issues that are not necessarily within their own constituency. Instead, every member participates with their own understandings based on their own positions and identities. Every single participant is a valued, heard, and fundamental part of the journey towards justice and change.

This piece was an exercise of feminist imagination that has envisioned how we can, and why we should, create a subset of feminism for the $99 \%$, one "that is inclusive, dialogic, decolonial and capable of envisioning expansive horizons of solidarity" (Mohanty, 2017, p. 12). It is high time for us to come together to bring this vision to life. 


\section{References}

Abou-Habib, L. (2019). Co-optation Versus Co-creation: Reflections on Building a Feminist Agenda. Kohl, 5(3). http://kohljournal.press/Cooptation-versus-cocreation

Alcoff, L. M. (2017). Decolonizing Feminist Philosophy. In M. McLaren (Eds.), Decolonizing Feminism: Transnational Feminism and Globalization, 21-36. Rowman \& Littlefield International Ltd.

Allouche, Y. (2020). In pictures: The women driving protests across the Arab world. Middle East Eye. https://www.middleeasteye.net/news/how-arab-women-have-defined-protests-middle-east

American-Arab Anti-Discrimination Committee. (2020, June 6). ADC Presents: Palestinian Solidarity with Black Communities with Noura Erakat, Ajamu Dillahunt, and Ahmad Abuznaid [Webinar]. Retrieved from Jadaliyya: https://www.jadaliyya.com/Details/41254/ADC-Presents-Palestinian-Solidarity-withBlack-Communities-with-Noura-Erakat,-Ajamu-Dillahunt,-and-Ahmad-Abuznaid

Arda, L. \& Banerjee, S. B. (2019). Governance in Areas of Limited Statehood: The NGOization of Palestine. Business \& Society, 1-33. https://doi.org/10.1177/0007650319870825

Badran, M. (1995). Feminists, Islam, and nation: gender and the making of modern Egypt. Princeton, N.J.: Princeton University Press.

Ben Salah, F. (2020). \#EnaZeda: Tunisian 'Me Too' movement met with both support and smear tactics. Middle East Eye. https://www.middleeasteye.nethnews/enazeda-tunisian-me-too-movementsupport-smear-campaigns

Bremer, J. (2011). Leadership and collective action in Egypt's popular committees: Emergence of authentic civic activism in the absence of the state. International Journal of Not-for-Profit Law, 13(4), 70-92. Retrieved from: https://heinonline.org/HOL/P?h=hein.journals/ijnpl13\&i=241

cooke, m. (2016) Women and the Arab Spring: A Transnational, Feminist Revolution. In Sadiqi F. (Eds) Women's Movements in Post-"Arab Spring" North Africa. Comparative Feminist Studies. Palgrave Macmillan, New York.

Danielson, R. E. (2007). Nasser and Pan-Arabism: Explaining Egypt's Rise to Power (Master's Thesis). Retrieved from https://calhoun.nps.edu/bitstream/handle/10945/3381/danielson07.pdf?sequence=3\&isAllowed=y

FM. (2016). Pan-Arabism. Retrieved from International Relations: http://internationalrelations.org/panarabism/

Jad, I. (2009). The NGO-isation of Arab Women's Movements. IDS Bulletin, 35, 34-42. 10.1111/j.17595436.2004.tb00153.x

Kandiyoti, D. (2013). Fear and Fury: women and post-revolutionary violence. Retrieved from Open Democracy: https://www.opendemocracy.net/en/5050/fear-and-fury-women-and-post-revolutionaryviolencel

Khamis, S. (2011). The Arab "Feminist" Spring? Feminist Studies, 37(3), 692-695. Retrieved from http://www.jstor.org/stable/23069929

Khamis, S., \& Mili, A. (2018). Arab Women's Activism and Socio-Political Transformation: Unfinished Gendered Revolutions. Palgrave Macmillan.

Leitz, L. (2019). Arab Feminist Union. Retrieved from Encyclopedia Britannica: https://www.britannica.com/topic/Arab-Feminist-Union 
Kohl 6.1

MEE and Agencies. (2020). Lebanese activist who kicked ministerial bodyguard in groin to face court. Middle East Eye. https://www.middleeasteye.net/news/lebanese-activist-famed-kicking-ministerialbodyguard-groin-face-court

Mitri, D. (2015). From Public Space to Office Space: the professionalization/NGO-ization of the feminist movement associations in Lebanon and its impact on mobilization and achieving social change. Civil Society Knowledge Center. https://civilsociety-centre.org/rac/papers

Mohanty, C. T. (2017). Toward a Decolonial Feminism for the 99 Percent. In M. McLaren (Eds.), Decolonizing Feminism: Transnational Feminism and Globalization, 7-11. Rowman \& Littlefield International Ltd.

Newsom, V. A. \& Lengel, L. (2012). Arab Women, Social Media and the Arab Spring: Applying the Framework of Digital Reflexivity to Analyze Gender and Online Activism. Journal of International Women's Studies 13(5), 31-45. Retrieved from: http://vc.bridgew.edu/jiws/vol13/iss5/5

Pohlhaus Jr., G. (2017). Knowing without Borders and the Work of Epistemic Gathering. In M. McLaren (Eds.), Decolonizing Feminism: Transnational Feminism and Globalization, 37-54. Rowman \& Littlefield International Ltd.

Sukarieh, M. (2015). The First Lady Phenomenon: Elites, States, and the Contradictory Politics of Women's Empowerment in the Neoliberal Arab world. Comparative Studies of South Asia, Africa and the Middle East, 35(3), 575-587. https://doi.org/10.1215/1089201X-3426421

Swarr, A. L., \& Nagar, R. (2010). Critical transnational feminist praxis. Albany, NY: SUNY Press.

Temlali, Y. (2016). The Arab Spring: Rebirth or Final Throes of Pan-Arabism. Retrieved from Heinrich Böll Stiftung website: https://www.boell.de/sites/default/files/assets/boell.de/images/download_de/Perspectives_0206_Yassine_Temlali.pdf

Wilson, C., Zabaneh, J. \& Dore-Weeks, R. (2019). Understanding the Role of Women and Feminist Actors in Lebanon's 2019 Protests. WN Women. https://www.un.org.lb/library/assets/UN\%20Women Lebanon\%27s\%202019\%20Protests042358.pdf

Yuval-Davis, N. (1994). Women, Ethnicity and Empowerment. Feminism \& Psychology, 4(1), 179-197. https://doi.org/10.1177/0959353594041010

Zaatari, Z. (2014). From Women's Rights to Feminism: The Urgent Need for an Arab Feminist Renaissance. In Makdisi, J. S., Bayoumi, N. \& Sidawi, R. R. (Eds.), Arab Feminisms: Gender and Equality in the Middle East, 54-65. London \& New York: I. B. Tauris \& Co. 